\title{
SEJARAH DINASTI BANI UMAIYYAH DAN PENDIDIKAN ISLAM
}

\author{
Muhammad Sapii Harahap \\ Program Studi Pendidikan Bahasa Arab STAI As-Sunnah \\ Jl. Medan-Tj. Morawa, KM 13, Gg. Darmo, Desa Bangun Sari, Kab. D. Serdang, Sumut \\ muhammadsapii23@gmail.com
}

\begin{abstract}
Abstrak Sejarah adalah sejumlah perubahan, kejadian dan pristiwa dalam kenyataan sekitar kita. Bani Umayyah/Dinasti Umayyah atau Kekhalifahan Umayyah, adalah kekhalifahan Islam pertama setelah masa Khulafaur Rasyidin Radhiallahu Anhum yang memerintah dari 661 sampai 750 di Jazirah Arab dan sekitarnya (Ibu Kota di Damaskus); serta dari 756 sampai 1031 di Cordoba, Spanyol sebagai Kekhalifahan Cordoba. Nama dinasti ini dirujuk kepada Umayyah bin 'Abd asy-Syams, kakek buyut dari khalifah pertama Bani Umayyah, yaitu Muawiyah bin Abu Sufyan Radhiallahu Anhu atau kadangkala disebut juga dengan Muawiyah Radhiallahu Anhu.

Ketika berbicara tentang pendidikan Islam maka wajib membicarakan dan mengambil semua ajaran Islam secara menyuluruh bukan sebagian saja. Pendidikan dalam Islam itu mengajarkan secara global dan detail kepada seluruh mahkluk terkhusus manusia. Pendidikan yang diajarkan Islam kepada manusia adalah mulai dari lahir kedunia sampai kembali ke akhirat dan dikabarkan kepada manusia tentang kehidupan setelah dunia dan syarat-syarat mendapatkan kebahagian dunia dan akhirat. Pendidikan Islam juga mengajarkan bagaimana menghadapi musuh di medan perang dan apa saja syarat musuh yang wajib diperangi. Ajaran Islam adalah ajaran yang rahmatan lil 'alamin bukan ajaran yang radikal seperti yang disebarkan segelintir manusia pada zaman sekarang ini.
\end{abstract}

Kata Kunci: Sejarah Dinasti Umayyah, Pendidikan, Islam.

\section{PENDAHULUAN}

Tulisan ini menjelaskan tentang sejarah Daulah/Dinasti Bani Umayyah mulai dari latar belakang berdirinya hingga kehancurannya adapun poin-poin yang akan dijelaskan ialah: Faktor-faktor berdirinya Khilafah Bani Umaiyyah, masa keemasan Dinasti Umayyah, faktor-faktor kemunduran Dinasti Umayyah, dan sejarah singkat tentang proses peralihan dari Dinasti Umayyah ke Dinasti Abbasiyah.

Penulis mengingatkan semua pembaca agar memahami dan mengamalkan firman Allah Subahanahu Wata'ala dan hadis Rasulullah Shallallahu 'Alaihi 
Wasallam, ketika mendengarkan dan bercerita tentang kisah-kisah para sahabat Rasulullah Shallallahu 'Alai Wasallam.

\section{Allah berfirman :}

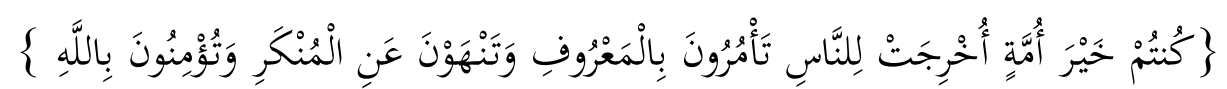

Artinya : " kalian adalah sebaik-baik ummat yang Allah keluarkan untuk manusia, karena kalian menegakkan amar ma'ruf dan nahi munkar dan beriman kepada Allah". 1

\section{Dalam hadits Rasulullah Shallallahu 'Alai Wasallam bersabda :}

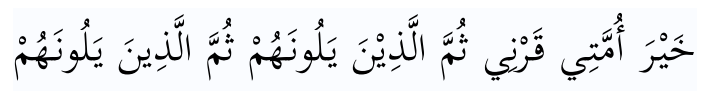

Artinya : "Sebaik-baik umatku adalah pada masaku. Kemudian orang-orang yang setelah mereka (generasi berikutnya), lalu orang-orang yang setelah mereka." 2

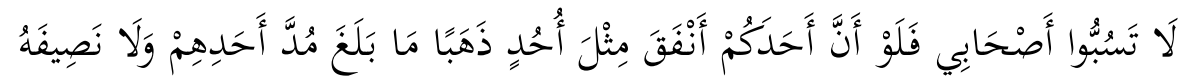

Artinya : " janganlah kalian mencela sahabatku; meskipun seseorang dari kalian menginfakkan emas sebesar gunung uhud, tidak akan bisa mengimbangi pahala infak mereka walau satu mud bahkan separohnya sekalipun". ${ }^{3}$

Adapun kesimpulan dari firman Allah Subahanahu Wata'ala, hadis Rasulullah Shallallahu 'Alaihi Wasallam adalah: (1) Ahlu Sunnah sepakat melarang untuk mencaci salah seorang dari sahabat Rasulullah karena perselisihan yang terjadi diantara mereka, meskipun telah diketahui siapa yang benar, karena itu terjadi tidak terlepas dari ijtihad masing-masing, sementara Allah Subahanahu Wata'ala telah memaafkan yang salah diantara mereka, bahkan yang salah masih dapat satu ganjaran, dan yang benar dapat dua ganjaran. (2) Sikap seorang muslim terhadap para sahabat adalah memuji mereka sebagaimana Allah memuji mereka, kalaupun ada beberapa pernyataan dari beberapa tokoh sejarawan yang seolah-olah mengarah kepada merendahkan salah seorang dari sahabat maka perlu diperhatikan kebenaran sanad riwayat tersebut, kalau ternyata benar maka kita tetap bersikap husnuz zhan kepada mereka (sahabat), karena tidak ada yang maksum setelah para nabi dan malaikatnya, bagaimanapun, kebaikan para sahabat jauh lebih banyak dibandingkan kesalahannya.

\footnotetext{
${ }^{1}$ QS.Ali Imran : 110.

${ }^{2}$ Shahih Al-Bukhari, no. 3650

${ }^{3}$ Bukhari, no. 3397 dan Muslim no. 4610 dan 4611, Al-Jami'us Shahih, jilid. 9 (Dar Thauq An-Najat, 1422 H), h.207
} 


\section{PEMBAHASAN}

\section{A. Pengertian Sejarah}

Pengertian sejarah dalam Kamus Umum Bahasa Indonesia mengandung 3 pengertian: 1) kesustraan lama: silsilah, asal usul, 2) kejadian dan peristiwa yang benar-benar terjadi pada masa lampau, 3) ilmu pengetahuan, cerita pelajaran tentang kejadian dan peristiwa yang benar-benar terjadi pada masa lampau. ${ }^{4}$

Sedangkan menurut ahli sebagaiman yang disebutkan R. M. Ali dalam bukunya, bahwa sejarah adalah : 1) sejumlah perubahan, kejadian dan pristiwa dalam kenyataan sekitar kita, 2) cerita tentang perubahan, kejadian dan peristiwa yang merupakan realitas kehidupan, 3) ilmu yang bertugas menyelidiki perubahan, kejadian dan peristiwa yang merupakan realitas tersebut. ${ }^{5}$

Berdasarkan beberapa pendapat diatas bahwa sejarah dapat diartikan dengan "menceritakan kembali atau mereviuw kejadian atau pristiwa di masa lampau dengan menggunakan berbagai sumber yang dipercaya berupa data atau nondata dan disusun dengan sistematis dengan menggunakan metode dan pendekatan tertentu. Seperti pada tulisan ini menceritakan bagaimana sejarah berdirinya Dinasti Umayyah dan pendidikan Islam di masa tersebut.

\section{B. Faktor-Faktor berdirinya Khilafah Bani Umaiyyah}

1- Hasan Radhiallahu Anhu Menjadi Khalifah

Setelah wafatnya Ali Radhiallahu Anhu di tangan Ibnu Muljim, Masyarakat Iraq (Kufah) langsung menyatakan bai'at terhadap Hasan Bin Ali Radhiallahu Anhuma pada hari itu juga ${ }^{6}$. Setelah acara bai' at selesai Hasan Radhiallahu Anhu berangkat menuju Syam sebab penduduk Syam sampai pada detik itu belum menampakkan ketaatan terhadap pemerintahan Ali Radhiallahu Anhu beliaupun bergegas berangkat dengan niat berdamai ke negeri Syam ${ }^{7}$.

\footnotetext{
${ }^{4}$ W.J.S Perwadarminta, Kamus Umum Bahasa Indonesia, (Jakarta: Gramedia. 1982), h. 646

${ }^{5}$ R. Moh. Ali. Pengantar Ilmu Sejarah Indonesia, (Yogyakarta: LKiS, 2005), h-11-12.

6 Yaitu pada bulan Ramadhan tahun 40 Hijriyah. Lihat Buku Kurikulum untuk Sekolah Menengah Pertama (SMP) di Universitas Muhammad bin Su'ud Saudi Arabia. 1416 H. AlKhulafaurrasyidun Dan Daulah Umawiyyah,h.101.

7 Utsman Khamis, Hiqbah Min at-Tarikh, (Pustaka :Imam Bukhari, Dar Kutub Mishriyah: 2006), hal.210.
} 
Hasan Bashri meriwayatkan hadits dari jalan Abu Bakrah dia berkata, aku mendengarkan Rasulullah Shallallahu 'Alaihi Wasallam berkata :

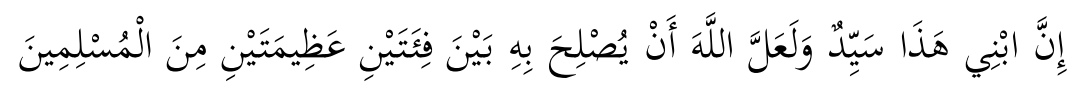

Artinya : "cucuku ini bakalan menjadi pemimpin, semoga dengan perantaranya Allah mendamaikan dua kelompok besar kaum muslimin ( yang bersengketa)". 8

Imam Zuhri meriwayatkan bahwa Mu'awiyah mengirim surat kepada Hasan Radhiallahu Anhu, di ujung surat tersebut Mu'awiyah Radhiallahu Anhu memberikan tawaran apa saja kepada Khalifah Hasan, begitu melihat surat tersebut 'Amr Bin 'Ash Radhiallahu Anhu langsung memberikan komentar : "Ini tidak mungkin dilakukan, saya berpendapat kita lebih baik berperang”.

Mu'awiyah Radhiallahu Anhu dengan sikap kebijaksanaannya menjelaskan kepada 'Amr Bin 'Ash bahwa berperang sesungguhnya jalan yang tidak mungkin ditempuh kecuali dalam kondisi terpaksa.

Akhirnya Mu'awiyah bertemu dengan Hasan, pertemuan tersebut membuahkan hasil yang sangat cemerlang yaitu Hasan Radhiallahu Anhu dengan tulus dan demi kemashlahatan kaum muslimin, menyerahkan kursi kekhilafahan kepada Mu'awiyah Radhiallahu Anhu Kepemimpinan Hasan Bin Ali Radhiallahu Anhu tidak berlangsung lama, beliau menjabat sebagai kepala Negara hanya selama lebih kurang enam bulan.

\section{2- Mu'awiyah bin Abu Sufyan Radhiallahu Anhu Menjadi Khalifah}

Sejak Khalifah Hasan Bin Ali mengundurkan diri dari khilafah, sejak itu pula Mu'awiyah resmi menjadi Khalifah kaum muslimin di Syiria (Syam), Iraq dan seluruh daerah Islam lainnya, tepatnya tahun 41 Hijriyah. Tahun ini disebut dengan sebutan amul jama'ah, karena ummat Islam kembali damai dibawah kepemimpinan satu khalifah.

Begitulah padamnya api fitnah yang sebelumnya begitu menyala-nyala dan menyedihkan, akhirnya dengan kehendak Allah kedamaian yang dinanti-nanti kaum muslimin pun tiba berkat agama, ketaqwaan dan kecerdasan Hasan Radhiallahu Anhu.

\footnotetext{
${ }^{8}$ HR al Bukhari, 2704.
} 
Sungguh benarlah ucapan Rasulullah Shallallahu 'Alaihi Wasallam tatkala ia bersabda :

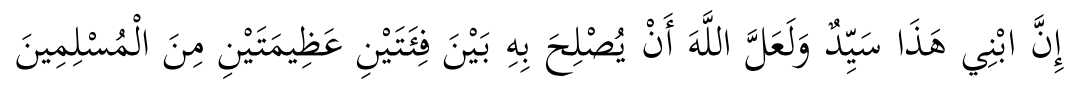

Artinya : "cucuku ini bakalan menjadi pemimpin, semoga dengan perantaranya Allah mendamaikan dua kelompok besar kaum muslimin ( yang bersengketa) ". 9

Hadis ini menunjukkan kemukjizatan Rasulullah Shallallahu 'Alaihi Wasallam dan pengangkatan Mu'awiyah menjadi khalifah memberikan kontribusi kebaikan kepada kaum muslimin, sekaligus bantahan terhadap kaum Syi'ah yang mencela kepribadian Mu'awiyah Radhiallahu Anhu.

Bani Umayyah/Dinasti Umayyah atau Kekhalifahan Umayyah, adalah kekhalifahan Islam pertama setelah masa Khulafaur Rasyidin Radhiallahu Anhum yang memerintah dari 661 sampai 750 di Jazirah Arab dan sekitarnya (Ibu Kota di Damaskus); serta dari 756 sampai 1031 di Cordoba, Spanyol sebagai Kekhalifahan Cordoba. Nama dinasti ini dirujuk kepada Umayyah bin 'Abd asySyams, kakek buyut dari khalifah pertama Bani Umayyah, yaitu Muawiyah bin Abu Sufyan Radhiallahu Anhu atau kadangkala disebut juga dengan Muawiyah Radhiallahu Anhu.

Para sejarawan membagi dinasti Umayyah ini menjadi dua, yaitu pertama dinasti yang dirintis oleh Muawiyah bin Abi Sofyan yang berpusat di Damaskus dan yang kedua dinasti Umayyah di Andalusia (Spanyol) yang pada awalnya merupakan wilayah taklukan Umayyah di bawah pimpinan seorang gubernur pada masa khalifah Walid bin Malik. Dan kemudian diubah menjadi kerajaan yang terpisah dari kekuasaan dinasti Abasiyah setelah berhasil menaklukan dinasti Umayyah di Damaskus. ${ }^{10}$

Pemindahan kekuasaan pada Mu'awiyyah Radhiallahu Anhu mengakhiri bentuk pemerintahan khulafaur rasyidin menjadi kerajaan atau Kekhalifaan monarchy heredetis (kerajaan turun temurun). Karena dia memberikan interpretasi baru dari kata-kata khalifah untuk mengagungkan jabatannya. Dia menyebutkan "khalifah Allah" dalam pengertian "penguasa" yang dipilih Allah. ${ }^{11}$ Ketika

\footnotetext{
${ }^{9}$ HR al Bukhari, 2704.

${ }^{10}$ Dedy Supriyadi, Sejarah Peradaban Islam. (Bandung: Pustaka Setia, 2008) h.103

${ }^{11}$ Badri Yatim, Sejarah Peradaban Islam. (Jakarta: Raja Grafindo Persada, 2008) h. 142
} 
Muawiyyah mewajibkan seluruh rakyat untuk menyatakan setia terhadap anaknya Yazid dimulailah penggantian secara turun-temurun yang berdasarkan politik, lebih dari pada kepentingan keagamaan. Di pengaruhi oleh keadaan Syiria (yang merupakan kaki tangan Bizantium sebelum adanya pemerintahan arab). Muawiyyah bermaksud mencontoh monarchy heriditas yang ada di Persia dan kaisar Bizantium. Yang mana deklarasi ini menyebabkan adanya pergerakan oposisi dari rakyat yang selanjutnya menyebabkan adanya perselisihan dan peperangan saudara. ${ }^{12}$ Dinasti Umayyah berkuasa hampir satu abad, tepatnya selama 90 tahun, dengan empat belas khalifah. Namun sebagian diantara mereka tidak mampu menjalankan tugasnya sebagai khalifah dengan baik mereka bukan hanya lemah tetapi juga bermoral buruk.

Berikut ini daftar nama Raja pada masa Dinasti Umayyah:

1- Muawiyah bin Sofyan (661-680 M)

2- Yazid bin Muawiyah (681-683 M)

3- Muawiyah bin Yazid (683-684 M)

4- Marwan bin Al-Hakam (684-685 M)

5- Abdul Malik bin Marwan(685-705M)

6- Al-walid bin Abdul Malik (705-715 M)

7- Sulaiman bin Abdul Malik (715-717 M)

8- Umar bin Abdul Aziz (717-720 M)

9- Yazid bin Abdul Malik (720-724 M)

10- Hisyam bin Abdul Malik (724-743 M)

11- Walid bin Yazid (743-744 M)

12- Yazid bin Walid (Yazid II) (744 M)

13- Ibrahim bin Malik (744 M)

14- Marwan bin Muhammad (745-750 M) $)^{13}$

\footnotetext{
12 Hassan Ibrahim Hassan, Sejarah Kebudayaan Islam (Yogjakarta: Kota kembang, 1997) h.66.

13 Abu Su'ud, Sejarah Ajaran dan Perannya dalam Peradaban Umat Manusia, (Jakarta: Rineka Cipta.2003), h. 66-67
} 
Untuk dapat melihat lebih jelas tentang keturunan khilafah-khilafah bani umaiyyah dapat dilihat pada struktur berikut :

Struktur Keturunan Khalifah-Khalifah Bani Umaiyyah ${ }^{14}$

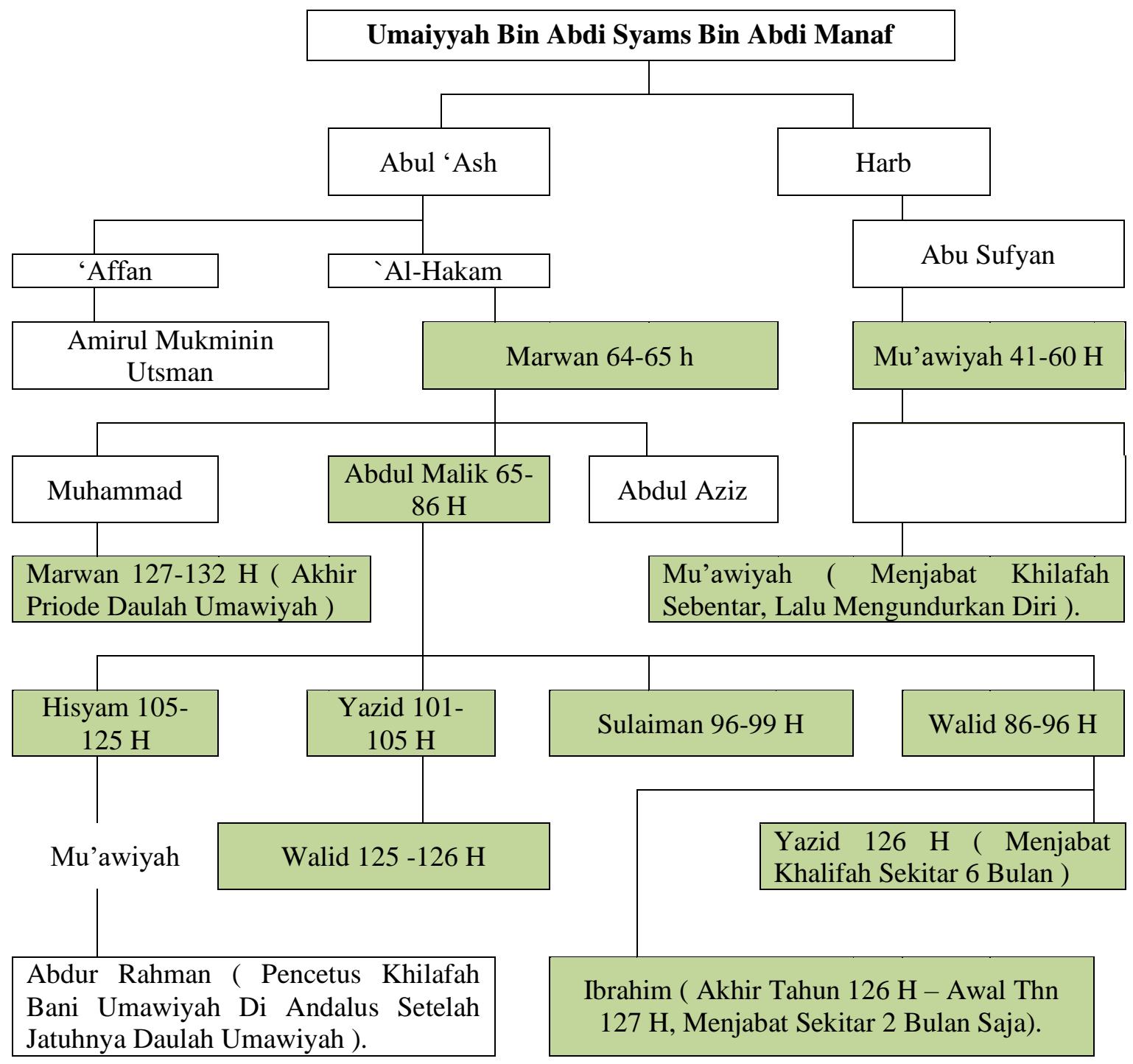

\section{Masa Keemasan Dinasti Umayyah}

Kemajuan Islam di masa Daulah Umayyah meliputi berbagai bidang, yaitu politik, ekonomi, sosial, ilmu pengetahuan dan Pendidikan Islam, seni dan budaya.

\section{1- Dibidang Politik}

${ }^{14}$ Al-Idaratul Ammah Litathwiiri Al-Khutat Wa Al-Manahij, Al-Khulafa Ar-Rasyidun Wa AdDaulah Al-Umawiyyah, h.155. 
Kekuasaan Bani Umayyah yang berumur kurang lebih 90 tahun. Ibu kota negara dipindahkan Mu'awiyah dari Madinah ke Damaskus, tempat ia berkuasa menjadi gubernur sebelumnya. Khalifah-khalifah besar dinasti Bani Umayyah ini adalah Muawiyah bin Abi Sufyan (661-680 M), Abd al-Malik bin Marwan (685705 M), al-Walid bin Abd Malik (705-715), Umar bin Abdul Aziz (717-720 M) dan Hisyam bin Abd al-Malik (724-743 M).

Ekspansi yang terhenti pada masa Usman dan Ali dilanjutkan oleh dinasti ini. Di zaman Mu'awiyah, Tunisia dapat ditaklukan. Di sebelah timur, Muawiyah dapat menguasai daerah Khurasan sampai ke sungai Oxus dan afganistan sampai ke Kabul. Angkatan-angkatan lautnya melakukan serangan-serangan ke Bizantium, Konstantinopel. Ekspansi ke timur yang dilakukan Muawiyah kemudian dilakukan oleh Abd al-Malik. Dia mengirim tentaranya menyebrangi sungai Oxus dan dapat berhasil menundukan Balk, Bukhara, Khawarizm, Ferghana dan Samarkand. Tentaranya bahkan sampai ke India dan dapat menguasai Balukhistan, Sind dan daerah Punjab sampai ke Maltan.

Ekspansi ke barat secara besar-besaran dilanjutkan oleh al-Walid bin Abd alMalik. Masa pemerintahan al-Walid adalah masa ketentraman, kemakmuran dan ketertiban. Umat Islam merasa hidup bahagia. Pada masa pemerintahannya yang berlangsung kurang lebih sepuluh tahun itu tercatat suatu ekspedisi militer dari Afrika Utara menuju wliyah barat daya, Benua Eropa, yaitu pada tahun $711 \mathrm{M}$ setelah al-Jazair dan Marokko dapat ditundukan, Thariq bin Ziyad, pemimpin pasukan Islam, dengan pasukannya menyeberangi laut yang memisahkan antara Marokko dengan benua Eropa, dan mendarat di suatu tempat yang sekarang dikenal dengan nama Gibraltar (Jabal Tariq). Tentara Spanyol dapat dikalahkan. Dengan demikian, Spanyol menjadi sasaran ekspansi selanjutnya. Ibu kota Spanyol, Kordova, dengan cepat dapat dikuasai. Menyusul setelah itu kota-kota lain seperti Seville, Elvira dan Toledo yang dijadikan ibu kota Spanyol yang baru setelah jatuhnya Kordova. Pasukan Islam memperoleh kemenangan dengan mudah karena mendapat dukungan rakyat setempat yang sejak lama menderita akibat kekejaman penguasa. Di zaman Umar bin Abd Aziz, serangan dilakukan ke Perancis melalui pegunungan Piranee. Serangan ini dipimpin oleh Abd al-Rahman bin Abdullah al-Ghafiqi. Ia mulai menyerang Bordeau, Poitiers. Dari sana dia 
menyerang Tours, namun peperangan yang terjadi di luar kota Tours, al-Ghafiqi terbunuh, dan tentaranya mundur kembali ke Spanyol. Disamping daerah-daerah tersebut di atas, pulau-pulau yang berada di laut tengah juga jatuh ke tangan Islam pada zaman Bani Umayyah ini.

Dengan keberhasilan ekspansi ke beberapa daerah, baik di timur maupun barat, wilayah kekuasaan Bani Umayyah ini betul-betul sangat luas. Daerah-daerah ini meliputi Spanyol, Afrika Utara, Syiria, Palestina, Jazirah Arabia, Irak, sebagian Asia kecil, Persia, Afganistan, daerah yang sekarang ini disebut Pakistan, Purkmenia, Uzbek, dan Kirgis di Asia Tengah.
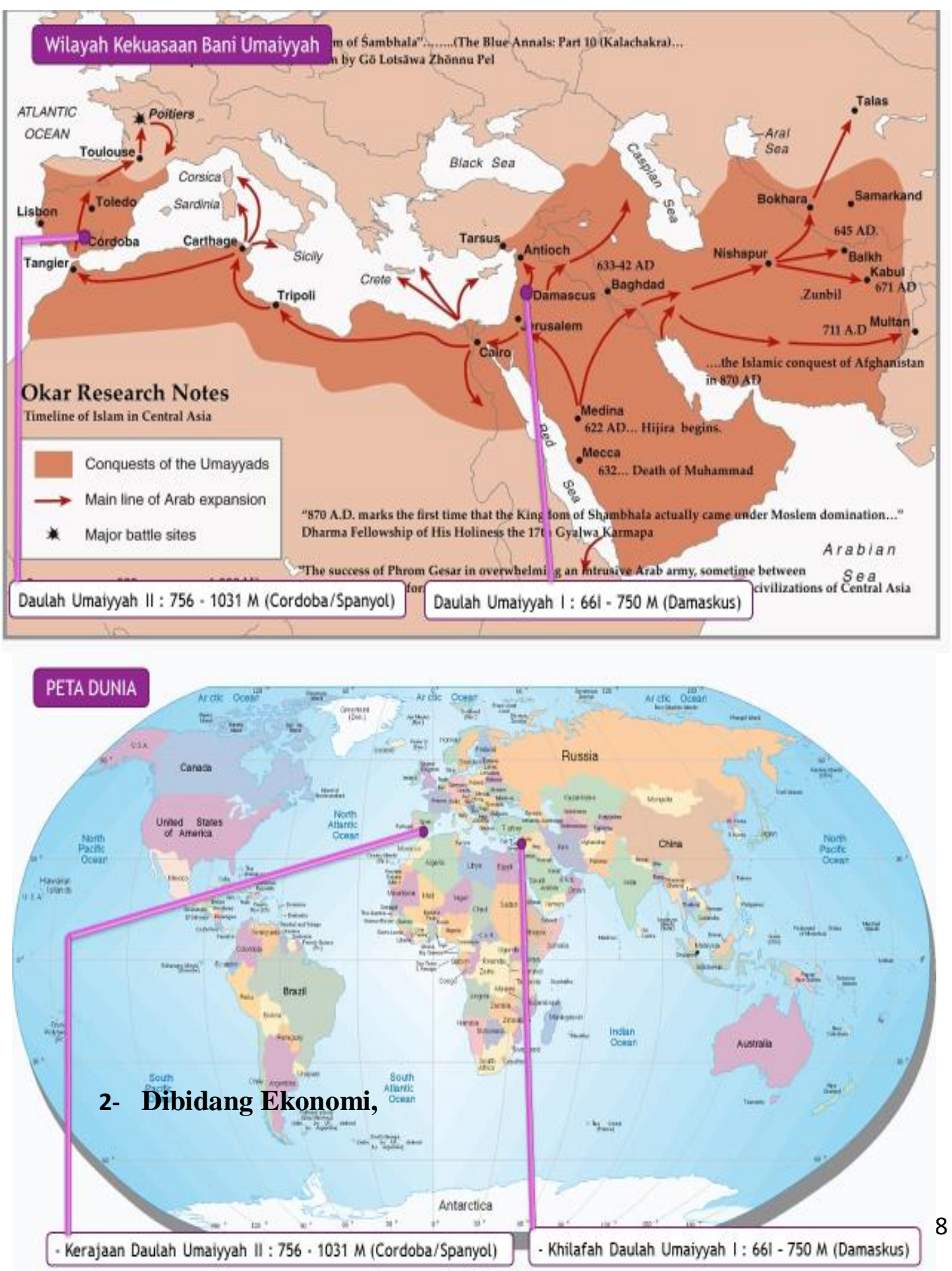
Bani Umayyah banyak berjasa dalam pembangunan di berbagai bidang. Muawiyah mendirikan dinas pos dan tempat-tempat tertentu dengan menyediakan kuda yang lengkap dengan peralatannya di sepanjang jalan. Dia juga berusaha menertibkan angkatan bersenjata dan mencetak mata uang. Pada masanya, jabatan khusus seorang hakim (qadhi) mulai berkembang menjadi profesi tersendiri, Qadhi adalah seorang spesialis dibidangnya. Abdul Malik mengubah mata uang Bizantium dan Persia yang dipakai di daerah-daerah yang dikuasai Islam. Untuk itu, dia mencetak uang tersendiri pada tahun $659 \mathrm{M}$ dengan memakai kata-kata dan tulisan Arab.

Khalifah Abdul Malik juga berhasil melakukan pembenahan-pembenahan administrasi pemerintahan memberlakukan bahasa Arab sebagai bahasa resmi administrasi Islam. Keberhasilan Khalifah Abdul Malik diikuti oleh putranya alWalid bin Abdul Malik (705-715 M) seorang yang berkemauan keras dan berkemampuan melaksanakan pembangunan. Dia membangun panti-panti untuk orang cacat. Semua personel yang terlibat dalam kegiatan yang humanis ini digaji oleh negara secara tetap. Dia juga membangun jalan-jalan raya yang menghubungkan suatu daerah dengan daerah lainnya, pabrik-pabrik, gedunggedung pemerintahan dan masjid-masjid yang megah. ${ }^{15}$

\section{3- Dibidang Sosial,}

Masa pemerintahan Bani Umayyah terkenal sebagai suatu era agresif, dimana perhatian tertumpu kepada usaha perluasan wilayah dan penaklukan, yang terhenti sejak zaman Khulafa ar-Rasyidin terakhir. Hanya dalam jangka waktu 90 tahun, banyak bangsa di penjuru empat mata angin beramai-ramai masuk kedalam kekuasaan Islam, yang meliputi tanah Spanyol, seluruh wilayah Afrika Utara, Jazirah Arab, Suriyah, Palestina, separuh daerah Anatolia, Irak, Persia, Afganistan, India dan negeri-negeri yang sekarang dinamakan Turkmenistan, Uzbekistan dan Kirgiztan yang termasuk Sovyet Rusia. ${ }^{16}$

\section{4- Dibidang Ilmu Pengetahuan dan Pendidikan Islam}

Ibu kota Daulah Umayyah pindah ke Damaskus, suatu kota tua di negeri Syam yang telah penuh dengan peninggalan kebudayaan maju sebelumnya. Daerah

\footnotetext{
${ }^{15}$ Badri Yatim, M.A, Sejarah Peradaban Islam, (Jakarta: PT. Raja Grafindo Persada. 1993), h. 43-45

${ }^{16}$ Ali Mufradi, Islam di Kawasan Kebudayaan, (Jakarta: Logos. 1997) h. 81
} 
kekuasaannya, selain yang diwariskan oleh Khulafa ar-Rasyidin, telah pula menguasai Andalus, Afrika Utara, Syam, Irak, Iran, Khurosan, terus ke Timur sampai benteng Tiongkok. Dalam daerah kekuasaannya terdapat kota-kota pusat kebudayaan, seperti: Yunani, Iskandariyah, Antiokia, Harran, Yunde, Sahfur, yang dikembangkan oleh ilmuwan-ilmuwan beragama Yahudi, Nasrani dan Zoroaster. Setelah masuk Islam para ilmuwan itu tetap memelihara ilmu-ilmu peninggalan Yunani itu, bahkan mendapat perlindungan. Di antara mereka ada yang mendapat jabatan tinggi di istana Khalifah. Ada yang menjadi dokter pribadi, bendaharawan, atau wazir, sehingga kehadiran mereka, sedikit banyak, mempengaruhi perkembangan ilmu pengetahuan.

Kemajuan Islam di masa Daulah Umayyah meliputi berbagai bidang, yaitu politik, ekonomi, sosial, ilmu pengetahuan, seni dan budaya. Di antaranya yang paling spektakuler adalah bertambahnya pemeluk Agama Islam secara cepat dan meluas. Semakin banyaknya jumlah kaum Muslimin ini terkait erat dengan makin luasnya wilayah pemerintahan Islam pada waktu itu. Pemerintah memang tidak memaksakan penduduk setempat untuk masuk Islam, melainkan mereka sendiri yang dengan rela hati tertarik masuk Islam. Akibat dari makin banyaknya orang masuk agama Islam tersebut maka pemerintah dengan gencar membuat program pembangunan Masjid di berbagai tempat sebagai pusat kegiatan kaum Muslimin. Pada masa Khalifah Abdul Malik, masjid-masjid didirikan di berbagai kota besar. Selain itu, beliau juga memperbaiki kembali tiga Masjid utama umat Islam, yaitu Masjidil Haram (Mekkah), Masjidil Aqsa (Yerusalem) dan Masjid Nabawi (Madinah). Al-Walid, Khalifah setelah Abdul Malik yang ahli Arsitektur, mengembangkan Masjid sebagai sebuah bangunan yang indah. Menara Masjid yang sekarang ada dimana-mana itu pada mulanya merupakan gagasan Al-Walid ini. Perhatian pada Masjid ini juga dilakukan oleh Khalifah-Khalifah Bani Umayyah setelahnya.

Perkembangan lain yang menggembirakan adalah makin meluasnya pendidikan Agama Islam. Sebagai ajaran baru, Islam sungguh menarik minat penduduk untuk mempelajarinya. Masjid dan tempat tinggal ulama merupakan tempat yang utama untuk belajar agama. Bagi orang dewasa, biasanya mereka belajar tafsir Alquran, hadis, dan sejarah Nabi Muhammad Shallalahu 'Alai 
Wasallam Selain itu, filsafat juga memiliki penggemar yang tidak sedikit. Adapun untuk anak-anak, diajarkan baca tulis Arab dan hafalan Alquran dan Hadis. Pada masa itu masyarakat sangat antusias dalam usahanya untuk memahami Islam secara sempurna. Jika pelajaran Alquran, hadis, dan sejarah dipelajari karena memang ilmu yang pokok untuk memahami ajaran Islam, maka filsafat dipelajari sebagai alat berdebat dengan orang-orang Yahudi dan Nasrani yang waktu itu suka berdebat menggunakan ilmu filsafat. Sedangkan ilmu-ilmu lain seperti ilmu alam, matematika, dan ilmu social belum berkembang. Ilmu-ilmu yang terakhir ini muncul dan berkembang dengan baik pada masa dinasti Bani Abbasiyah maupun Bani Umayyah Spanyol.

Ketika berbicara tentang pendidikan Islam maka wajib membicarakan dan mengambil semua ajaran Islam secara menyuluruh bukan sebagian saja. Pendidikan dalam Islam itu mengajarkan secara global dan detail kepada seluruh mahkluk terkhusus manusia. Pendidikan yang diajarkan Islam kepada manusia adalah mulai dari lahir kedunia sampai kembali ke akhirat dan dikabarkan kepada manusia tentang kehidupan setelah dunia dan syarat-syarat mendapatkan kebahagian dunia dan akhirat. Pendidikan Islam juga mengajarkan bagaimana menghadapi musuh di medan perang dan apa saja syarat musuh yang wajib diperangi. Ajaran Islam adalah ajaran yang rahmatan lil 'alamin bukan ajaran yang radikal seperti yang disebarkan segelintir manusia pada zaman sekarang ini. Salahsatu contoh Islam adalah ajaran rahmatan lil 'alamin ketika perluasan daerah Islam di masa Rasulullah Shallalohu 'Alaihi Wasallam, khulafaur rasidin radiallohu 'anhum serta pada dinasti Umayyah ini.

Buraidah Radiallohu 'anhu mengatakan bahwa ketika Rasulullah Shallalohu 'Alai Wasallam menugaskan panglima yang membawa pasukan menuju pertempuran, beliau senantiasa berpesan kepada panglima tersebut dan kaum muslimin yang menyertainya, utamanya pesan takwa kepada Allah dan pesan atas kebaikan. Lalu, Rasulullah Shallalohu 'Alai Wasallam bersabda, "berperanglah atas nama Allah! Di jalan Allah! Perangilah orang yang ingkar kepada Allah! Berperanglah dan janganlah curang, jangan berkhianat, jangan berlaku kejam (memotong hidung dan telinga) dan jangan membunuh anak-anak (bayi)! 
Apabila kamu bertemu kaum musyrikin yang menjadi musuhmu, maka tawarkan kepada mereka tiga pilihan, yang manapun salah satunya dari tiga itu yang mereka pilih, maka terimalah dan janganlah mereka diserang, lalu ajaklah mereka masuk Islam. Apabila mereka menerima ajakanmu, maka terimalah dan janganlah mereka diserang. Kemudian ajaklah mereka untuk berpindah dari perkampungan mereka menuju perkampungan orang-orang muhajirin. Jika mereka mau pindah, beritahu kepada mereka bahwa mereka mendapatkan hak dan kewajiban yang sama seperti orang-orang muhajirin. Jika mereka tidak mau pindah dari rumah mereka, maka beritahu kepada mereka bahwa mereka diperlakukan seperti kaum muslimin yang ada di pedalaman dengan diberlakukan hukum Allah atas mereka seperti yang berlaku atas orang-orang mukmin yang lain tanpa mendapatkan bagian dari ghanimah (harta rampasan yang didapat dari pertempuran) dan bagian dari Fai (harta rampasan yang didapat tanpa pertempuran, misalnya musuh melarikan diri), kecuali jika mereka turut berjihad bersama kaum muslimin.

Jika mereka tidak mau masuk Islam, maka suruhlah mereka membayar pajak. Jika mereka bersedia, maka terimalah dan janganlah mereka diperangi. Apabila mereka menolak, maka mintalah pertolongan Allah dan perangilah mereka! ${ }^{17}$

Sebagian dari banyak contoh bukti ajaran Islam atau pendidikan Islam yang rahmatan lil 'alamin adalah sebagaimana yang dijelaskan pada hadis diatas, sikap yang wajib dikerjakan/diamalkan seorang muslim ketika hendak berperang dan ketika peperangan berlangsung selalu diingatkan hadis Rasulullah Shallalohu 'Alai Wasallam diatas, adapun sikap yang wajib dikerjakan/diamalkan seorang muslim adalah:

1- Bertakwa kepada Allah,

2- Selalu berbuat baik,

3- Berperanglah atas nama Allah! Di jalan Allah!

a. Perangilah orang yang ingkar kepada Allah!

b. Berperanglah dan janganlah curang, jangan berkhianat, jangan berlaku kejam (memotong hidung dan telinga) dan jangan membunuh anak-anak (bayi)!

\footnotetext{
17 Muslim.(No.4522/1731), Shohihul Muslim , (Darussalam, Saudia Arabia. cetakan ke 2, Muharram 1421 H/April 2000 M) h. 768.
} 
4- Apabila kamu bertemu kaum musyrikin yang menjadi musuhmu, maka tawarkan kepada mereka tiga pilihan, yang manapun salah satunya dari tiga itu yang mereka pilih, maka terimalah dan janganlah mereka diserang, yaitu:

a. Ajaklah mereka masuk Islam, jika mereka mau maka,

i. Ajaklah mereka untuk berpindah dari perkampungan mereka menuju perkampungan orang-orang muhajirin. Jika mereka mau pindah, beritahu kepada mereka bahwa mereka mendapatkan hak dan kewajiban yang sama seperti orangorang muhajirin.

ii. Jika mereka tidak mau pindah dari rumah mereka, maka beritahu kepada mereka bahwa mereka diperlakukan seperti kaum muslimin yang ada di pedalaman dengan diberlakukan hukum Allah atas mereka seperti yang berlaku atas orangorang mukmin yang lain tanpa mendapatkan bagian dari ghanimah (harta rampasan yang didapat dari pertempuran) dan bagian dari Fai (harta rampasan yang didapat tanpa pertempuran, misalnya musuh melarikan diri), kecuali jika mereka turut berjihad bersama kaum muslimin.

b. Jika mereka tidak mau masuk Islam, maka suruhlah mereka membayar pajak,

c. Apabila mereka menolak, maka mintalah pertolongan Allah dan perangilah mereka!

Ulama-ulama mazhab yang terkenal yang hidup pada masa Dinasti Bani Umayyah adalah:

1- Imam Abu Hanifa (Nu'man bin Tsabit bin Zuta bin Mahan at-Taymi) ulama fiqih dan Hadis di Kufah, Irak (80 H / 699 M - 148 H / 767 M) lahir pada masa Khalifah ke lima yaitu Khalifah Abdul Malik bin Marwan (685$705 \mathrm{M})$ dan wafat Rahimahullah pada masa pemerintahan Dinasti Abbasiyah khalifah ke dua yaitu khalifah Abu Ja'far Al-Manshur (754-775 M). dan 
2- Imam Mālik (Mālik ibn Anas bin Malik bin 'Āmr al-Asbahi) Ulama Fiqih dan Hadis di Madinah (93 H/714 M - 179 H/800M) lahir pada masa Khalifah ke enam yaitu khalifah Al-walid bin Abdul Malik (705-715 M) dan wafat Rahimahullah pada masa pemerintahan Dinasti Abbasiyah khalifah ke lima yaitu khalifah Harun Ar-Rasyid (786-809 M).

\section{5- Dibidang Seni Dan Budaya.}

Bidang seni dan budaya pada masa itu juga mengalami perkembangan yang maju. Karena ajaran Islam lahir untuk menghapuskan perbuatan syirik yang menyembah berhala, maka seni patung dan seni lukis binatang maupun lukis manusia tidak berkembang. Akan tetapi, seni kaligrafi, seni sastra, seni suara, seni bangunan, dan seni ukir berkembang cukup baik. Di masa ini sudah banyak bangunan bergaya kombinasi, seperti kombinasi Romawi-Arab maupun PersiaArab. Apalagi, bangsa Romawi dan Persia sudah memiliki tradisi berkesenian yang tinggi. Khususnya dalam bidang seni lukis, seni patung maupun seni arsitektur bangunan. Contoh dari perkembangan seni bangunan ini, antara lain adalah berdirinya Masjid Damaskus yang dindingnya penuh dengan ukiran halus dan dihiasi dengan aneka warna-warni batu-batuan yang sangat indah. Perlu diketahui bahwa untuk membangun Masjid ini, Khalifah Walid mendatangkan 12.000 orang ahli bangunan dari Romawi. Tetapi di antara kemajuan-kemajuan yang terjadi pada masa Daulah Bani Umayyah tersebut, prestasi yang paling penting dan berpengaruh hingga zaman sekarang adalah luasnya wilayah Islam. Dengan wilayah yang sedemikian luas itu ajaran Islam menjadi cepat dikenal oleh bangsa-bangsa lain, tidak saja bangsa Arab.

\section{Faktor-faktor Kemunduran Dinasti Umayyah}

Sepeninggal Umar bin Abdul-Aziz, kekuasaan Bani Umayyah dilanjutkan oleh Yazid bin Abdul-Malik (720- 724 M). Masyarakat yang sebelumnya hidup dalam ketenteraman dan kedamaian, pada masa itu berubah menjadi kacau. Dengan latar belakang dan kepentingan etnis politis, masyarakat menyatakan konfrontasi terhadap pemerintahan Yazid bin Abdul-Malik cendrung kepada kemewahan dan kurang memperhatikan kehidupan rakyat. Kerusuhan terus berlanjut hingga masa pemerintahan khalifah berikutnya, Hisyam bin AbdulMalik (724-743 M). Bahkan pada masa ini muncul satu kekuatan baru dikemudian hari menjadi tantangan berat bagi pemerintahan Bani Umayyah. Kekuatan itu 
berasal dari kalangan Bani Hasyim yang didukung oleh golongan Mawali. Walaupun sebenarnya Hisyam bin Abdul-Malik adalah seorang khalifah yang kuat dan terampil, akan tetapi, karena gerakan oposisi ini semakin kuat, sehingga tidak berhasil dipadamkannya. ${ }^{18}$

Setelah sekian lama mengalami masa-masa kemunduran, akhirnya dinasti Bani Umayyah benar-benar mengalami kehancuran atau keruntuhan. Keruntuhan ini terjadi pada masa pemerintahan Marwan bin Muhammad setelah memerintah kurang lebih 6 tahun (744-750 M).

Keruntuhan dinasti Bani Umayyah ditandai dengan kekalahan Marwan bin Muhammad dalam pertempuran zab hulu melawa pasukan Abu Muslim alKhurasani pada tahun 748 M. pada peristiwa itu terjadi pembersihan etnis terhadap anggota keluarga Bani Umayyah. Selain itu, pasukan Marwan bin Muhammad yang ditawan dibunuh. Sementara yang tersisa dan masih hidup, terus dikejar dan kemudian dibunuh. Bahkan Marwan bin Muhammad yang sempat melarikan diri dapat ditangkap dan kemudian dibunuh oleh pasukan Abu Muslim al-Khurasani.

Pertikaian dan pembunuhan ini menimbulkan kekacauan sosial dan politik, sehingga negara menjadi tidak aman dan masyarakat yang pernah merasa tersisih bersatu dengan kelompok Abu Muslim dan Abul Abbas. Bergabungnya masyarakat untuk mengalahkan kekuatan Bani Umayyah, menandai berakhirnya masa-masa kejayaan Bani Umayyah, sehingga sekitar tahun 750 M Bani Umayyah tumbang.

Selain itu, Dinasti Bani Umayyah mengalami masa kemunduran, ditandai dengan melemahnya sistem politik dan kekuasaan karena banyak persoalan yang dihadapi para penguasa dinasti ini. Diantaranya adalah masalah polotik, ekonomi, dan sebagainya. ${ }^{19}$

Dalam buku Sejarah Kebudayaan Islam karya Murodi menjelaskan sebabsebab kemunduran dinasti Bani Umayyah adalah sebagai berikut:

1. Khalifah memiliki kekuasaan yang absolute. Khalifah tidak mengenal kompromi. Menentang khalifah berarti mati. Contohnya adalah peristiwa pembunuhan Husein dan para pengikutnya di Karbala. Peritiwa ini

\footnotetext{
${ }^{18}$ Zubaidah Siti, Sejarah Perdaban Islam, Perdana Publishing, Medan, Oktober 2016.h.83-84

${ }^{19}$ Murodi, Sejarah Kebudayaan Islam, (Semarang: PT. Karya Toha Putra. 1987), h. 26
} 
menyimpan dendam dikalangan para penentang Bani Umayyah. Sehingga selama masa-masa kekhalifahan Bani Umayyah terjadi pergolakan politik yang menyebabkan situasi dan kondisi dalam negeri dan pemerintahan terganggu.

2. Gaya hidup mewah para khalifah. Kebiasaan pesta dan berfoya-foya dikalangan istana, menjadi faktor penyebab rendahnya moralitas mereka, disamping mengganggu keuangan Negara. Contohnya, Khalifah Abdul Malik bin Marwan dikenal sebagai seorang khalifah yang suka berfoyafoya dan memboroskan uang Negara. Sifat-sifat inilah yang tidak disukai masyarakat, sehingga lambat laun mereka melakukan gerakan pemberontakan untuk menggulingkan kekuasaan dinasti Bani Umayyah.

3. Tidak adanya ketentuan yang tegas mengenai sistem pengangkatan khalifah. Hal ini berujung pada perebutan kekuasaan diantara para calon khalifah.

4. Banyaknya gerakan pemberontakan selama masa-masa pertengahan hingga akhir pemerintahan Bani Umayyah. Usaha penumpasan para pemberontak menghabiskan daya dan dana yang tidak sedikit, sehingga kekuatan Bani Umayyah mengendur.

5. Pertentangan antara Arab Utara (Arab Mudhariyah) dan Arab Selatan (Arab Himariyah) semakin meruncing, sehingga para penguasa Bani Umayyah mengalami kesulitan untuk mempertahankan kesatuan dan persatuan serta keutuhan Negara.

6. Banyaknya tokoh agama yang kecewa dengan kebijaksanaan para penguasa Bani Umayyah, karena tidak didasari dengan syari'at Islam. ${ }^{20}$

Sedangkan dari sumber lain, secara garis besar dapat disimpulkan kemunduran Dinasti Umayyah terbagi menjadi dua faktor, yaitu:

1- Faktor Internal

Beberapa alasan mendasar yang sangat berpengaruh terhadap keruntuhan Dinasti Umayyah adalah karena kekuasaan wilayah yang sangat luas tidak dibaringi dengan komunikasi yang baik, sehingga menyebabkan suatu kejadian yang mengancam keamanan tidak segera diketahui oleh pusat.

${ }^{20}$ Ibid, h. 27-28 
Selanjutnya mengenai lemahnya para khalifah yang memimpin. Diantara khalifah-khalifah yang ada, hanya beberapa saja khalifah yang cakap, kuat, dan pandai dalam mengendalikan stabilitas negara. Selain itu, di antara mereka pun hanya bisa mengurung diri di istana dengan hidup bersama gundik-gundik, minum-minuman keras, dan sebagainya. Situasi semacam ini pun mengakibatkan munculnya konflik antar golongan, para wazir dan panglima yang sudah berani korup dan mengendalikan negara.

\section{2- Faktor Eksternal}

Intervensi luar yang berpotensi meruntuhkan kekuasaaan Dinasti Umayyah berawal pada saat Umar II berkuasa dengan kebijakan yang lunak, sehingga baik Khawarij maupun Syiah tak ada yang memusuhinya. Namun, segala kelonggaran kebijakan-kebijakan tersebut mendatangkan konsekuensi yang fatal terhadap keamanan pemerintahannya. Semasa pemerintahan Umar II ini, gerakan bawah tanah yang dilakukan oleh Bani Abbas mampu berjalan lancar dengan melakukan berbagai konsolidasi dengan Khawarij dan Syiah yang tidak pernah mengakui keberadaan Dinasti Umayyah dari awal. Setelah Umar II wafat, barulah gerakan ini melancarkan permusuhan dengan Dinasti Umayyah. Gerakan yang dilancarkan untuk mendirikan pemerintahan Bani Abbasyiah semakin kuat. Pada tahun $446 \mathrm{M}$ mereka memproklamasikan berdirinya pemerintah Abbasyiah, namun Marwan menangkap pemimpinnya yang bernama Ibrahim lalu dibunuh. Setelah dibunuh, pemimpin gerakan diambil alih oleh seorang saudaranya bernama Abul Abbas asSaffah yang berangkat bersama-sama dengan keluarganya menuju Kuffah. Kedudukan kerajaan Abbasyiah tidak akan tegak berdiri sebelum khalifahkhalifah Umayyah tersebut dijatuhkan terlebih dahulu. ${ }^{21}$

As-Saffah mengirim suatu angkatan tentara yang terdiri dari laskar pilihan untuk menentang Marwan, dan mengangkat pamannya Abdullah bin Ali untuk memimpin tentara tersebut. Antara pasukan Abdullah bin Ali dan Marwan pun bertempur dengan begitu sengitnya di lembah Sungai Dzab, yang sampai akhirnya pasukan Marwan pun kalah pada pertempuran itu.

Sepeninggal Marwan, maka benteng terakhir Dinasti Umayyah yang diburu Abbasyiah pun tertuju kepada Yazid bin Umar yang berkududukan di Wasit.

\footnotetext{
${ }^{21}$ Ahmad al-Usairy, Sejarah Islam (Jakarta Akbar. 2007), h. 211.
} 
Namun, pada saat itu Yazid mengambil sikap damai setelah mendengar berita kematian Marwan. Di tengah pengambilan sikap damai itu lantas Yazid ditawari jaminan keselamatan oleh Abu Ja'far al-Mansur yang akhirnya Yazid pun menerima baik tawaran tersebut dan disahkan oleh As-Saffah sebagai jaminannya. Namun, ketika Yazid dan pengikut-pengikutnya telah meletakkan senjata, Abu Muslim al-Khurasani menuliskan sesuatu kepada As-Saffah yang menyebabkan Khalifah Bani Abbasyiah itu membunuh Yazid beserta para pengikutnya.

Dari uraian kemunduran dan kehancuran Daulah Bani Umayyah diatas, merupakan sunnatullah bahwa setiap kekuasaan dan peradaban akan mencapai puncak kemajuannya, dan akan menelusuri jurang kehancurannya dikemudian hari.

Allah berfirman :

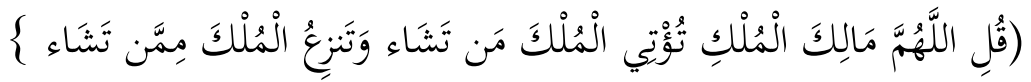

“Katakanlah wahai tuhanku pemiliki kerajaan, engkau menganugerahkan kerajaan bagi orang yang engkau kehendaki, dan mencabutnya dari orang yang engkau kehendaki". ${ }^{22}$

\section{E. Proses Peralihan dari Bani Dinasti Umayyah ke Dinasti Abbasiyah}

Setelah Hisyam bin Abdul-Malik wafat, khalifah-khalifah Bani Umayyah yang tampil berikutnya bukan hanya lemah tetapi juga bermoral buruk. Hal ini semakin memperkuat golongan oposisi, dan akhirnya pada tahun $750 \mathrm{M}$, Daulah Bani Umayyah digulingkan oleh Bani Abbasiyah yang merupakan bahagian dari Bani Hasyim itu sendiri, dimana Marwan bin Muhammad, khalifah terakhir Bani Umayyah, walaupun berhasil melarikan diri ke Mesir, namun kemudian berhasil ditangkap dan terbunuh di sana. Kematian Marwan bin Muhammad menandai berakhirnya kekuasaan Bani Umayyah di Timur (Damaskus) yang digantikan oleh Daulah Abbasiyah, dan dimulailah era baru Bani Umayyah di Barat, Al-Andalus.

\section{Simpulan}

Dinasti Umayyah atau Kekhalifahan Umayyah, adalah kekhalifahan Islam pertama setelah masa Khulafaur Rasyidin yang memerintah dari 661 sampai 750

${ }^{22}$ QS. Ali Imran : 26 . 
di Jazirah Arab dan sekitarnya (Ibu Kota di Damaskus); serta dari 756 sampai 1031 di Cordoba, Spanyol sebagai Kekhalifahan.

Corak yang ditempuh Muawiyah dalam memilih calon pemimpin adalah dengan memakai sistem pemerintahan monarki here-detis yaitu system kerajaan turun-menurun. Masa pemerintahan Bani Umayyah terkenal sebagai suatu era agresif, dimana perhatian tertumpu kepada usaha perluasan wilayah dan penaklukan, yang terhenti sejak zaman Khulafa ar-Rasyidin terakhir. Hanya dalam jangka waktu 90 tahun, banyak bangsa di penjuru empat mata angin beramai-ramai masuk kedalam kekuasaan Islam, yang meliputi tanah Spanyol, seluruh wilayah Afrika Utara, Jazirah Arab, Suriyah, Palestina, separuh daerah Anatolia, Irak, Persia, Afganistan, India dan negeri-negeri yang sekarang dinamakan Turkmenistan, Uzbekistan dan Kirgiztan yang termasuk Sovyet Rusia.

\section{Pustaka Acuan}

Al-Idaratul Ammah Litathwiiri Al-Khutat Wa Al-Manahij, Al-Khulafa ArRasyidun Wa Ad-Daulah Al-Umawiyyah.

Al-Usairy, Ahmad. Sejarah Islam. Jakarta: Akbar. 2007.

Bukhari, Al-Jami'us Shahih, Thauq An-Najat, 1422 H.

Buku Kurikulum untuk Sekolah Menengah Pertama (SMP) di Universitas Muhammad bin Su'ud Saudi Arabia. 1416 H. Al-Khulafaurrasyidun dan Daulah Umawiyyah.

Departemen Agama RI, Mushaf Al-Qur'an Terjemah, edisi tahun 2002, Depok: Alhuda, 2005.

Ibrahim, Hassan. Sejarah Kebudayaan Islam.Yogjakarta: Kota kembang. 1997.

MN.Ary B, Uraian Kritis Terhadap Buku Ta'lim Muta'allim, http : www.Altavista.com, 6 Juli 2007.

Mufradi, Ali. Islam di Kawasan Kebudayaan, Jakarta: Logos. 1997

Murodi. Sejarah Kebudayaan Islam, Semarang: PT. Karya Toha Putra. 1987.

Muslim, Shohihul Muslim, (Darussalam, Saudia Arabia. cetakan ke 2, Muharram $1421 \mathrm{H} /$ April $2000 \mathrm{M}$ )

R. Moh. Ali. Pengantar Ilmu Sejarah Indonesia, (Yogyakarta: LKiS, 2005) 
Su'ud, Abu. Sejarah Ajaran dan Perannya dalam Peradaban Umat Manusia. Jakarta: Rineka Cipta. 2003.

Sunanto, Musyrifah. Sejarah Islam Klasik Perkembangan Ilmu Pengetahuan Islam. Jakarta: Prenada Media. 2004.

Supriyadi, Dedy. Sejarah Peradaban Islam. Bandung: Pustaka Setia. 2008

Utsman Khamis, Hiqbah min at-Tarikh, Pustaka : Imam Bukhari, Dar Kutub Mishriyah:2006.

W.J.S Perwadarminta, Kamus Umum Bahasa Indonesia, (Jakarta: Gramedia. 1982)

Yatim, Badri. Sejarah Peradaban Islam. Jakarta: Raja Grafindo Persada. 2008.

Zubaidah Siti, Sejarah Perdaban Islam, Perdana Publishing, Medan, Oktober 2016. 